\title{
GDF11/BMP11 activates both smad1/5/8 and smad2/3 signals but shows no significant effect on proliferation and migration of human umbilical vein endothelial cells
}

\author{
Yong-Hui Zhang ${ }^{1}$, Feng Cheng ${ }^{1}$, Xue-Ting Du ${ }^{1}$, Jin-Lai Gao ${ }^{1}$, Xiao-Lin Xiao ${ }^{1}, \mathrm{Na} \mathrm{Li}^{1}$, \\ Shan-Liang $\mathrm{Li}^{1}$ and De-Li Dong ${ }^{1}$ \\ ${ }^{1}$ Department of Pharmacology (The State-Province Key Laboratories of Biomedicine-Pharmaceutics of China, Key Laboratory \\ of Cardiovascular Research, Ministry of Education), Translational Medicine Research and Cooperation Center of Northern \\ China, Heilongjiang Academy of Medical Sciences, Harbin Medical University, Harbin, P.R.China \\ Correspondence to: De-Li Dong, email: dongdeli@ems.hrbmu.edu.cn \\ Keywords: bone morphogenetic protein 11, growth differentiation factor 11, smad2/3, smad1/5/8, endothelial cells, Pathology \\ Section \\ Received: November 07, $2015 \quad$ Accepted: February 09, $2016 \quad$ Published: February 23, 2016
}

\section{ABSTRACT}

GDF11/BMP11, a member of TGF- $\beta$ superfamily, was reported to rejuvenate heart, skeletal muscle and blood vessel architecture in aged mice. However, the rejuvenative effects of GDF11 were questioned recently. Here, we investigated the effects of GDF11 on smad and non-smad signals in human umbilical vein endothelial cells (HUVECs) and the effects of GDF11 on proliferation and migration of HUVECs and primary rat aortic endothelial cells (RAECs). GDF11 factor purchased from two different companies (PeproTech and R\&D Systems) was comparatively studied. Western blot was used to detect the protein expressions. The cell viability and migration were examined by using MTT and wound healing assays. Results showed that GDF11 activated both smad1/5/8 and smad2/3 signals in HUVECs. GDF11 increased protein expression of NADPH oxidase 4(NOX4) in HUVECs. GDF11 showed no significant effect on the protein level of p38, p-p38, ERK, p-ERK, Akt, p-Akt (Ser473) and p-Akt(Thr308), but increased the protein level of p-JNK and p-AMPK in HUVECs, and these increases were inhibited by antioxidant mitoTEMPO treatment. GDF11 slightly increased cell viability after short-term treatment and slightly decreased cell viability after long-term treatment. GDF11 showed no significant effect on cell proliferation and migration. These data indicated that the notion of GDF11 as a rejuvenation-related factor for endothelial cells needs to be cautious.

\section{INTRODUCTION}

Growth differentiation factor 11(GDF11), also known as bone morphogenetic protein 11(BMP11), was first cloned and characterized from rat incisor pulp RNA as a member of bone morphogenetic protein/transforming growth factor $\beta$ (BMP/TGF- $\beta$ ) superfamily [1]. Like other members of the TGF- $\beta$ superfamily, GDF11 binds to type II receptors, and then the complex recruits activin type I receptors ALK4, ALK5 and ALK7 to activate smad $2 / 3$ proteins (R-smads) pathway, which associates with common mediator smad4. The smad protein complex translocates into the nucleus and interacts with transcriptional co-activators or co-repressors to regulate promoter activity to positively or negatively control gene expression.

GDF11 not only contributes to embryonic development and histogenesis, but also plays a role in metabolic disorders, and cancers [2,3]. Recently, several noticeable studies showed that GDF11 rejuvenated heart and skeletal muscle in aged mice [4], and GDF11 increased proliferation of brain capillary endothelial cells, migration of endothelial progenitor cells and improved the vascular and neurogenic rejuvenation of the aging mouse brain $[5,6]$. However, the rejuvenative effects of GDF11 were questioned by other studies. These reports doubted the decrease of circulating GDF11 level in aging muscle, heart, and brain phenotypes [7, 8], and restoring GDF11 in old mice had no effect on cardiac structure or function [9]. Besides, GDF11/BMP11 had deleterious effects on aging 
skeletal muscle [8]. Thus, it is essential to investigate the effects of GDF11 on endothelial cells, which correlate with multiple cardiovascular diseases.

Since GDF11 belongs to BMP/TGF- $\beta$ superfamily, the canonical signals induced by BMP/TGF- $\beta$ superfamily should be the basis of GDF11 action. Therefore, in the present work, we firstly identified the effects of GDF11 on smad and non-smad signals in human umbilical vein endothelial cells (HUVECs), and then studied the effects of GDF11 on cell viability, proliferation and migration of HUVECs. In order to ensure the reliability of results, we used GDF11 factor purchased from two different companies (PeproTech and R\&D Systems) to treat HUVECs and primary rat aortic endothelial cells (RAECs). We found that GDF11 activated both smad1/5/8 and smad2/3 signals but showed no significant effects on proliferation and migration of HUVECs.

\section{RESULTS}

\section{GDF11 activates both smad1/5/8 and smad2/3 signals in HUVECs}

Activating smad1/5/8 is the typical action of BMP members [10] and activating $\operatorname{smad} 2 / 3$ is the typical action of TGF- $\beta$ members [11]. We speculated that GDF11 should have the properties of both BMPs and TGF- $\beta$, so we firstly examined the effects of GDF11 on $\operatorname{smad} 1 / 5 / 8$ and smad2/3 signals in HUVECs. As shown in Figure 1A and $1 B$, GDF11 significantly activated both smad1/5/8 and smad2/3 signals in HUVECs. GDF11 treatment did not affect the total $\operatorname{smad} 2 / 3$ and total $\operatorname{smad} 1 / 5 / 8$ expressions in protein level (data not shown). The time-course of smad1/5/8 and smad2/3 activation by GDF11 treatment was different. For smad1/5/8 signal, the peak of GDF11induced smad1/5/8 activation appeared at $0.25 \mathrm{~h}$ after treatment; with the time lapsing, the activation declined and disappeared after $24 \mathrm{~h}$. For smad2/3 signal, the activation by GDF11 was constant during the treatment time from 0 to $48 \mathrm{~h}$. Activation of smad $2 / 3$ signaling pathway increased the expression of NOX4 in the endothelial cells, fibroblasts, human pulmonary artery smooth muscle cells and breast cancer cells [12-15] and activation of the smad2/3/NOX $4 / \mathrm{H}_{2} \mathrm{O}_{2}$ signaling pathway had a positive role in cell proliferation and cell migration of endothelial cell [15]. Therefore, we tested the effect of GDF11 on NOX4 protein expressions in HUVECs. GDF11 treatment $(50 \mathrm{ng} / \mathrm{ml})$ increased NOX4 protein level after 24 and $48 \mathrm{~h}$ treatment (Figure 2). NOX4 induces the production of hydrogen peroxide $\left(\mathrm{H}_{2} \mathrm{O}_{2}\right)$ and superoxide anion $\mathrm{O}^{2-}[16,17]$, suggesting that GDF11 would have ROS-related actions.
A

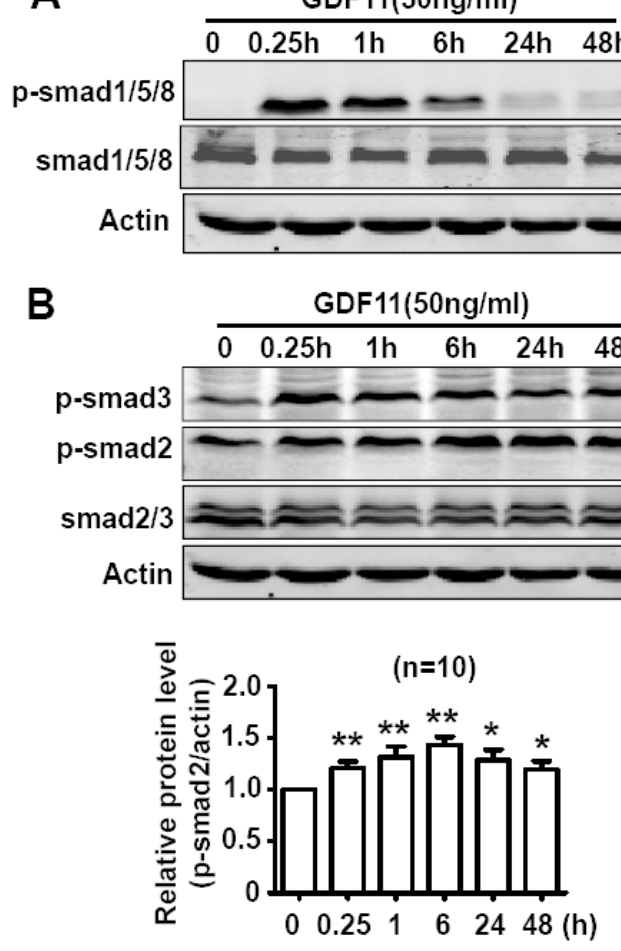

GDF11(50ng/ml)

\begin{tabular}{llllll}
\hline 0 & $0.25 \mathrm{~h}$ & $1 \mathrm{~h}$ & $6 \mathrm{~h}$ & $24 \mathrm{~h}$ & $48 \mathrm{~h}$
\end{tabular}
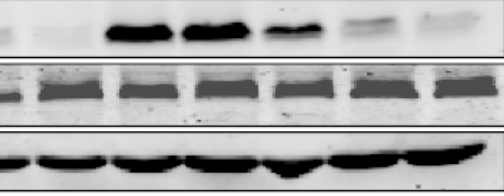

GDF11(50ng/ml) $60 \mathrm{kD}$ $52 / 56 \mathrm{kD}$ $43 k D$

\begin{tabular}{lllllll}
\cline { 2 - 6 } & 0 & $0.25 \mathrm{~h}$ & $1 \mathrm{~h}$ & $6 \mathrm{~h}$ & $24 \mathrm{~h}$ & $48 \mathrm{~h}$
\end{tabular}
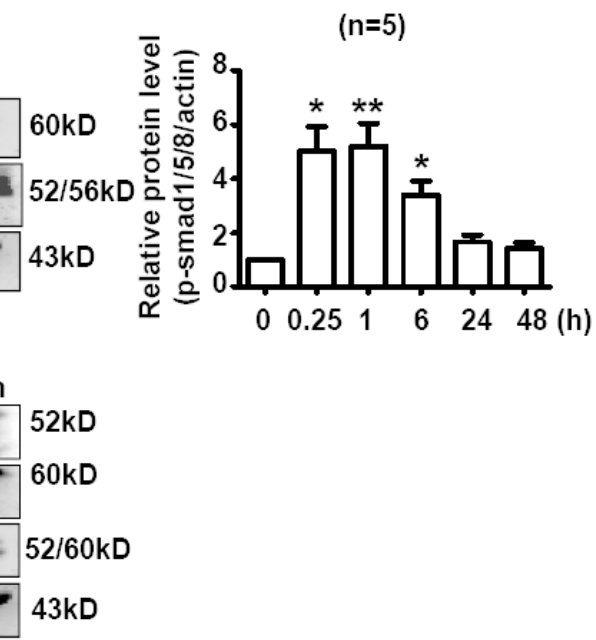

Figure 1: GDF11 activates both smad1/5/8 signal and smad2/3 signals in HUVECs. A. The time-course of GDF11-induced smad1/5/8 activation in HUVECs. $* P<0.05 v s$. control $(0 \mathrm{~h}), * * P<0.01 v s$. control $(0 \mathrm{~h}) . n=5$. B. The time-course of GDF11-induced smad $2 / 3$ activation in HUVECs. $* P<0.05$ vs. control $(0 \mathrm{~h}), * * P<0.01$ vs. control (0h). $n=10$. 
The effects of GDF11 on MAPKs, Akt, and AMPK signals in HUVECs

Non-smad pathways are also involved in the biological functions of BMP and TGF- $\beta$ members $[18$, 19], then, we examined the effects of GDF11 on MAPKs, Akt and AMPK signals in HUVECs. GDF11 showed no significant effect on the protein levels of p38, p-p38, ERK, and p-ERK during the treatment period from 0 to $48 \mathrm{~h}$ (Figure $3 \mathrm{~A}$ and $3 \mathrm{~B}$ ), but increased p-JNK after 24 and $48 \mathrm{~h}$ treatment (Figure 3C). Antioxidant mitoTEMPO $(25 \mathrm{nM})$ inhibited the GDF11-induced increase of p-JNK expression at 48h (Figure 3D), indicating that GDF11induced JNK activation was ROS-dependent. GDF11 treatment did not affect total JNK expression in protein level (data not shown). GDF11 showed no effect on the protein levels of Akt, p-Akt (Ser473) and p-Akt (Thr308) during the treatment period from 0 to $48 \mathrm{~h}$ (Figure 4). GDF11 $(50 \mathrm{ng} / \mathrm{ml})$ activated AMPK $48 \mathrm{~h}$ post-treatment and mitoTEMPO (25nM) inhibited GDF11-induced AMPK activation in HUVEC cells (Figure 5A and 5B).

Effects of GDF11 on cell viability, cell migration and cell proliferation in endothelial cells

It was reported that $\mathrm{H}_{2} \mathrm{O}_{2}$ promoted endothelial cell growth at a low dose and induced cell apoptosis at a higher dose [20]. Firstly, We tested the effects of tert-Butyl hydroperoxide(t-BHP), which was a derivative of $\mathrm{H}_{2} \mathrm{O}_{2}$ and was used as lipid peroxide prototype to induce free radical production [21], on cell viability of HUVECs. The t-BHP-induced changes of cell viability were associated
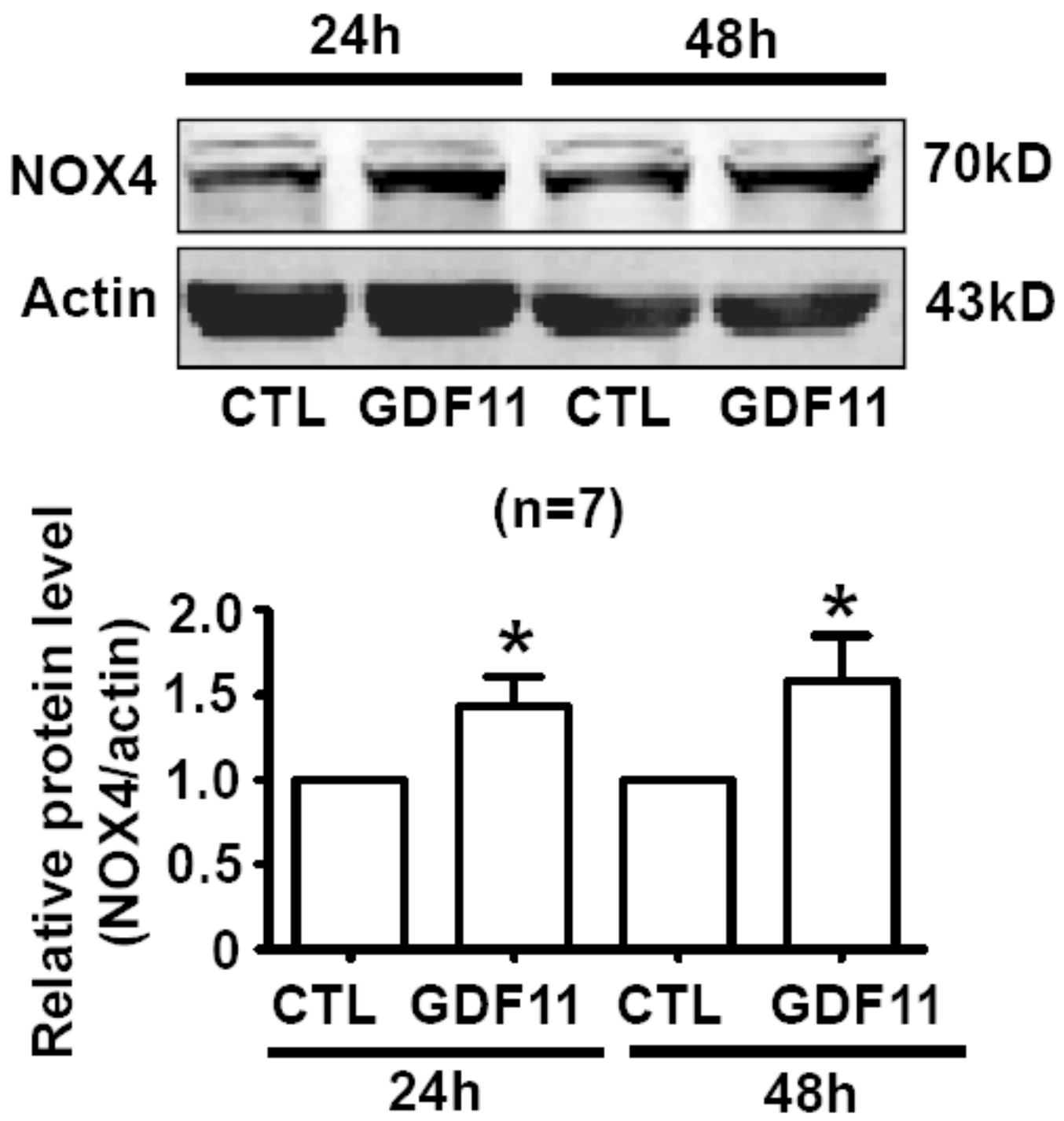

Figure 2: GDF11 increases NOX4 protein expressions. NOX4 protein level was increased after GDF11 (50ng/ml) treatment for $24 \mathrm{~h}$ and $48 \mathrm{~h}$ in HUVEC cells. $* P<0.05$ vs. control. $n=7$. 
with the t-BHP concentrations. In the range from 200 to $300 \mu \mathrm{M}$, t-BHP increased the cell viability, but in the range from 500 to $700 \mu \mathrm{M}$, t-BHP decreased the cell viability (Figure 6A). Then, we examined the effects of GDF11 on cell viability of HUVECs. As shown in Figure 6B, GDF11 slightly increased the cell viability after $24 \mathrm{~h}$ treatment, and slightly decreased the cell viability after 72 and $96 \mathrm{~h}$ treatment. Live- and dead-cell staining assay showed that GDF11 did not induce cell death (Figure 6C). By using GDF11 purchased from another company (R\&D Systems), the cell viability was not apparently changed in HUVECs (Figure 6D). We further studied the effects of GDF11 purchased from two different companies (PeproTech and R\&D Systems) on cell viability of primary rat aortic endothelial cells (RAECs). Both of GDF11 slightly reduced the cell viability after $48 \mathrm{~h}$ treatment (Figure $6 \mathrm{E}$ and Figure 6F). Comprehensive analysis of above data indicated that GDF11 increased the cell viability after short time treatment but decreased the cell viability after long time treatment. However, whatever the increase or decrease, the extent of changes was too small to be meaningful.

Next, we examined the effects of GDF11 on cell proliferation and cell migration of HUVECs. GDF11 showed no significant effect on cell proliferation and cell migration in HUVECs and RAECs (Figure 7 and Figure 8).
A
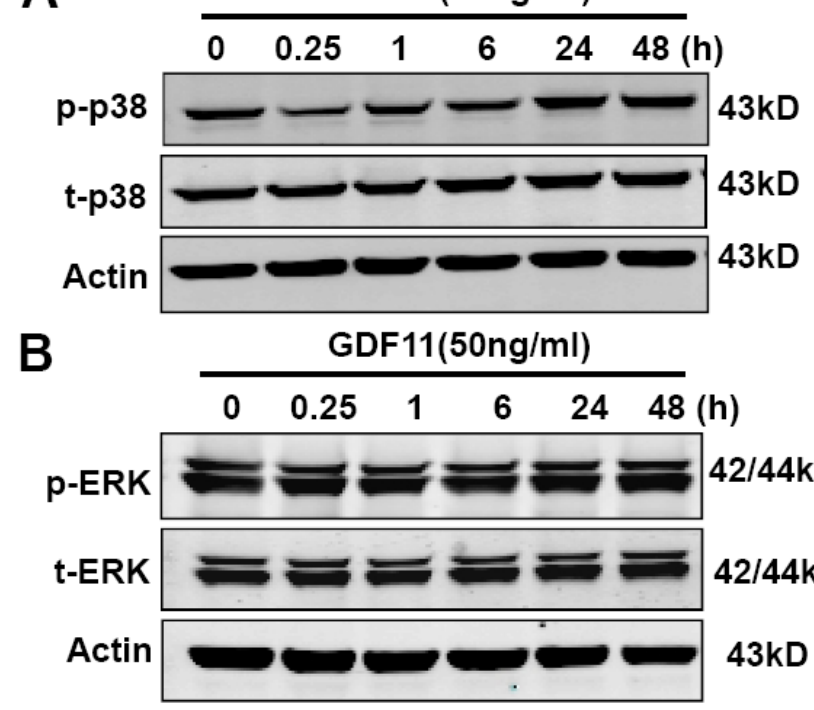

C
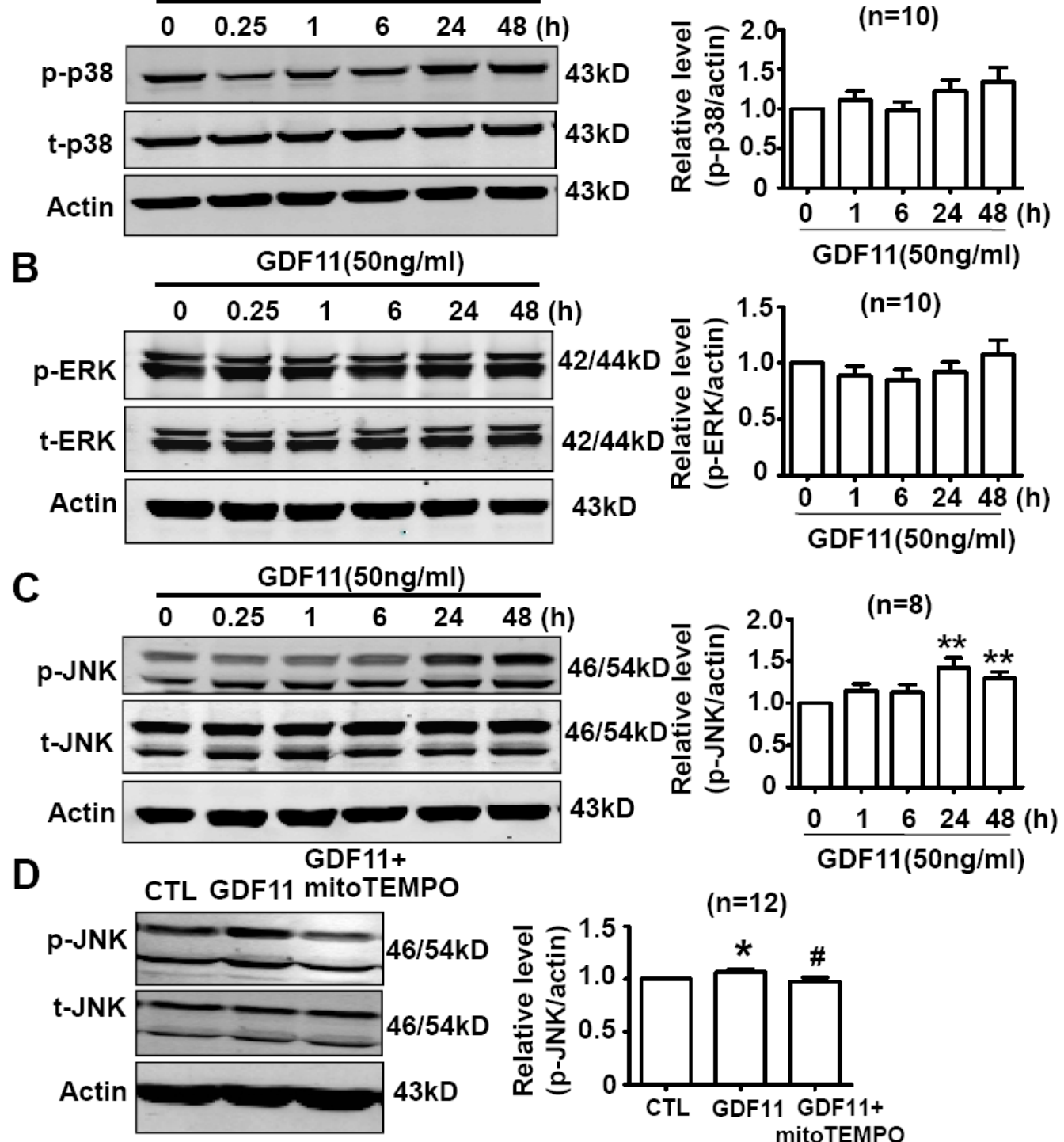

Figure 3: Effects of GDF11 on MAPK signals in HUVECs. (A.-B.) GDF11 had no significant effect on p38 and ERK MAPK signals in HUVECs. $n=10$ C. GDF11 increased the protein level of p-JNK after at GDF11 treatment for 24h and 48h in HUVECs. $* * P<0.01$ vs. control. $n=8$. D. MitoTEMPO inhibited GDF11-induced JNK activation in HUVECs. The cells were pre-treated with mitoTEMPO $(25 \mathrm{nM})$ for $1 \mathrm{~h}$ and then GDF11 $(50 \mathrm{ng} / \mathrm{ml})$ was added. ${ }^{*} P<0.05$ vs. control. $\# P<0.05$ vs. GDF11 treatment group. $n=12$. 


\section{Effects of GDF11 on eNOS expression in HUVECs}

eNOS plays an important role in maintenance of vascular homeostasis. Inhibition of ROS generation in endothelial cells restored ROS-induced decrease of p-eNOS levels [22]. Since GDF11 induced NOX4 upregulation, we examined the effects of GDF11 on eNOS expression in HUVECs. As shown in Figure 9A, the time-course of eNOS expressions showed that GDF11 significantly reduced p-eNOS(Ser1177) expression in protein level after $48 \mathrm{~h}$ treatment. Western blot with parallel control also demonstrated that GDF11 reduced p-eNOS(Ser1177) expression in protein level after $48 \mathrm{~h}$ treatment(Figure 9B). The decreased p-eNOS(Ser1177) protein level was restored by antioxidant mitoTEMPO, indicating that GDF11-induced down-regulation of p-eNOS was ROS-dependent in HUVECs (Figure 9C).

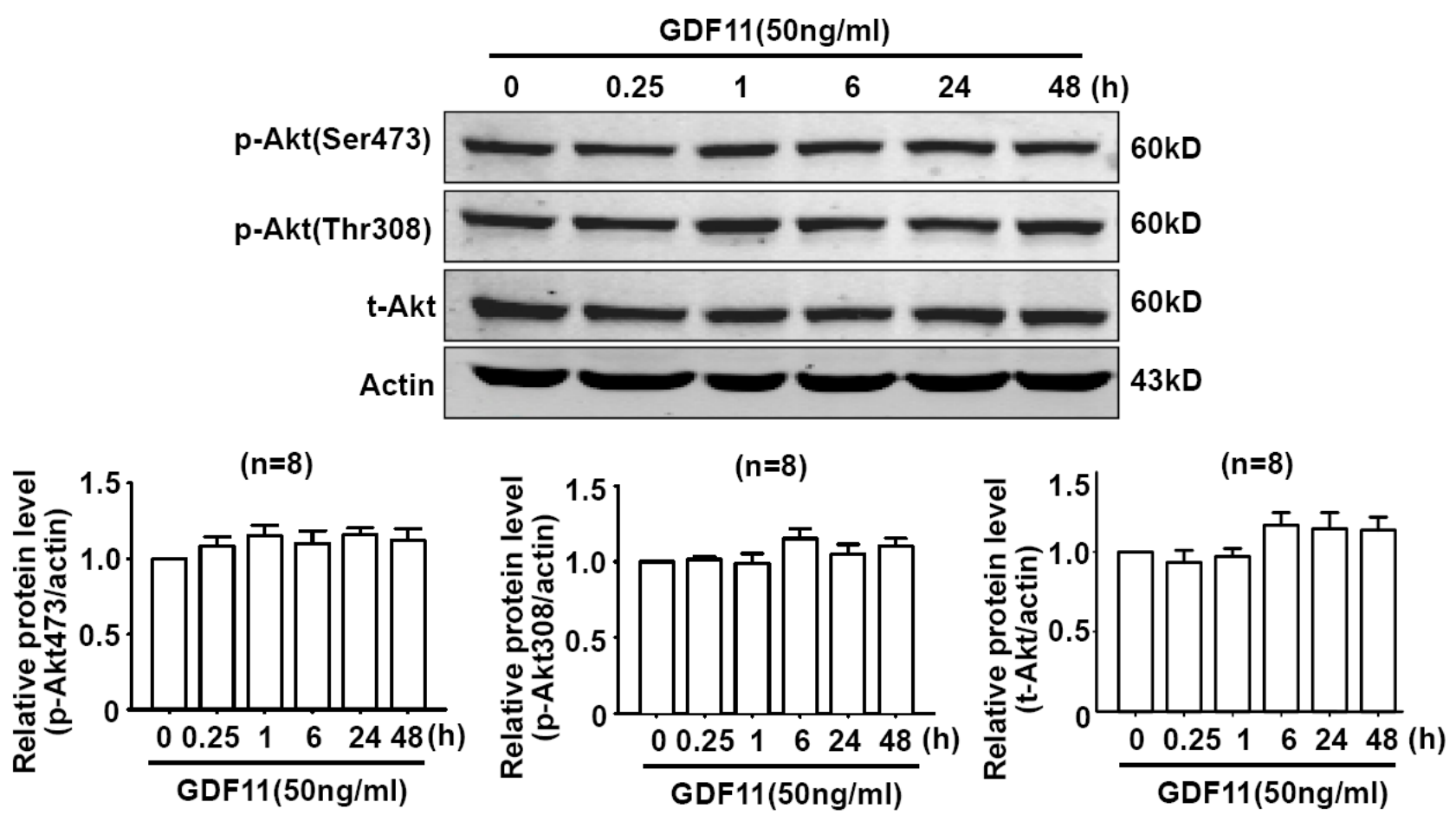

Figure 4: GDF11 has no effect on Akt signal in HUVECS. GDF11 had no significant effect on the level of p-Akt(Ser473), p-Akt(Thr308) and total Akt protein following GDF11 stimulation in HUVEC cells. $n=8$.
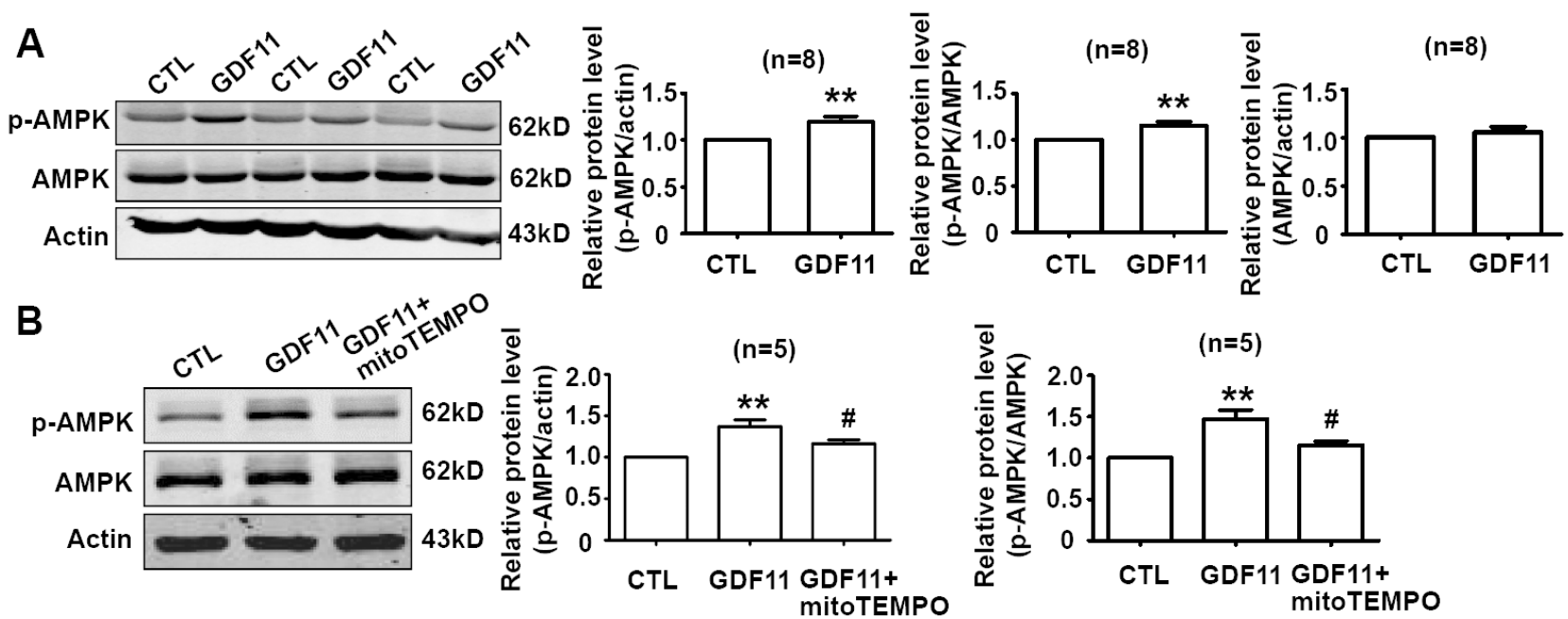

Figure 5: GDF11 induces AMPK activation which is inhibited by mitoTEMPO. A. GDF11 increased the protein level of p-AMPK after GDF11 treatment (50ng/ml) for 48h in HUVECs. ${ }^{* *} P<0.01 v s$. control. $n=8$. B. MitoTEMPO inhibited GDF11-induced MAPK activation in HUVECs. The cells were pre-treated with mitoTEMPO $(25 \mathrm{nM})$ for $1 \mathrm{~h}$ and then GDF $11(50 \mathrm{ng} / \mathrm{ml})$ was added. ${ }^{* *} P<$ 0.01 vs. control.\# $P<0.05$ vs. GDF11 treatment group. $n=5$. 


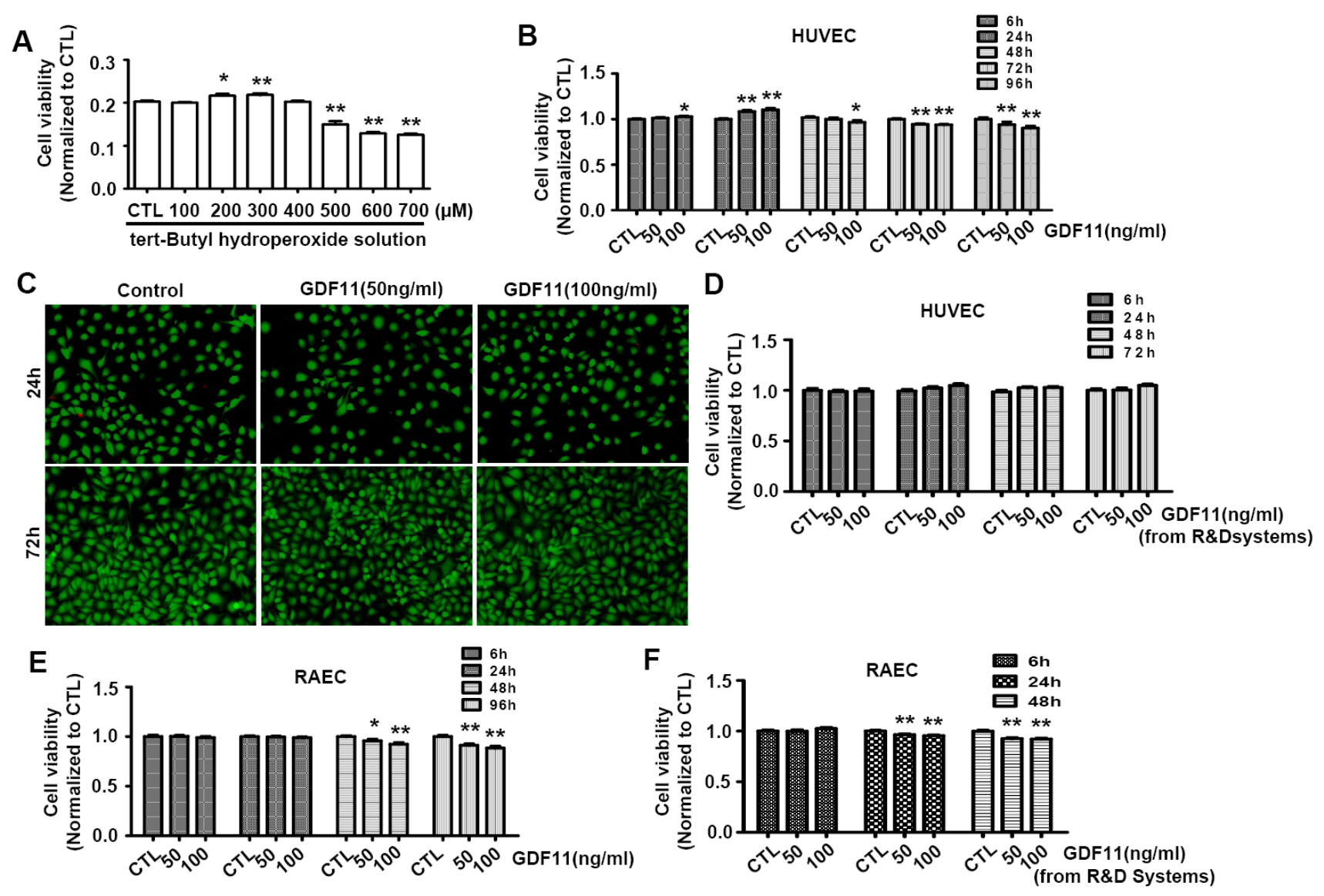

Figure 6: Effects of GDF11 on cell viability in HUVECs and RAECs. A. Tert-Butyl hydroperoxide increased cell viability at $200 \mu \mathrm{M}$ and $300 \mu \mathrm{M}$ doses and decreased cell viability in the doses from 500 to $700 \mu \mathrm{M}$ after $6 \mathrm{~h}$ treatment. $* P<0.05 v s$. control. $* * P<$ 0.01 vs. control. B. GDF11 (50ng/ml) purchased from PeproTech slightly increased cell viability after $24 \mathrm{~h}$ treatment and slightly decreased cell viability after $72 \mathrm{~h}$ and $96 \mathrm{~h}$ treatment in HUVECs. GDF11 $(100 \mathrm{ng} / \mathrm{ml})$ purchased from PeproTech slightly increased the cell viability in HUVEC cells at $6 \mathrm{~h}$ and $24 \mathrm{~h}$ and decreased the cell viability at $48 \mathrm{~h}, 72 \mathrm{~h}$ and $96 \mathrm{~h} . * P<0.05 v s$. control. $* * P<0.01 v s$. control. C. The representative photos of live and dead cell staining. The live cells were stained with calcein AM in green, and the dead cells were stained with ethidium homodimer-1 in red. D. GDF11 purchased from R\&D Systems showed no significant effect on cell viability of HUVECs. E. GDF11 purchased from PeproTech slightly decreased cell viability after 48h and 96h treatment in aortic endothelial cells (RAECs). $* P<0.05$ vs. control. $* * P<0.01$ vs. control. F. GDF11 purchased from R\&D Systems slightly decreased cell viability after $24 \mathrm{~h}$ and $48 \mathrm{~h}$ treatment in aortic endothelial cells (RAECs). ${ }^{* *} P<0.01 v s$. control.

A

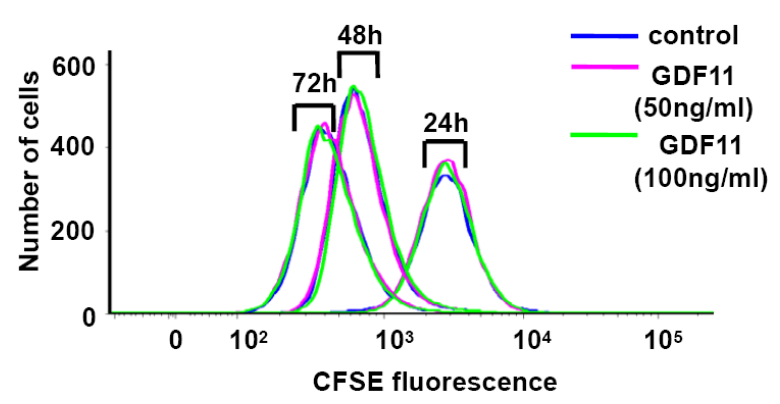

B

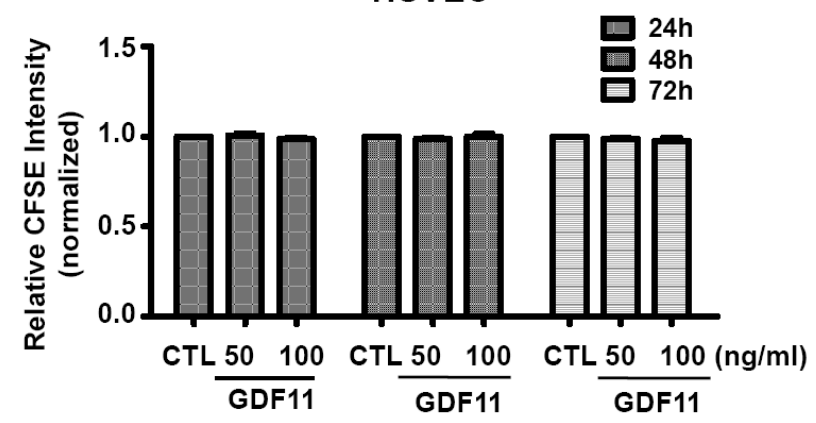

Figure 7: GDF11 shows no significant effect on cell proliferation of HUVECs. Cell proliferation was measured by carboxyfluorescein diacetate succinimidyl ester (CFSE) staining and analyzed by flow cytometry. $n=6$. 
A
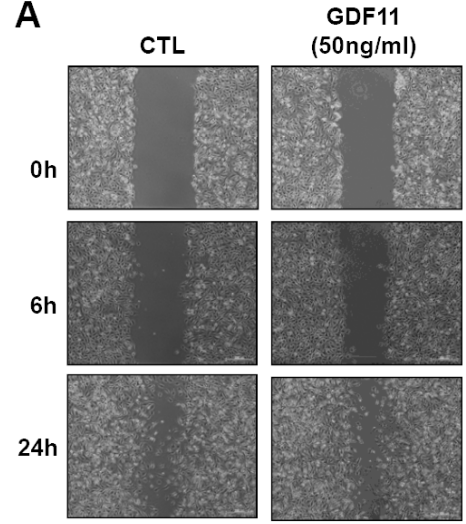

\section{B}

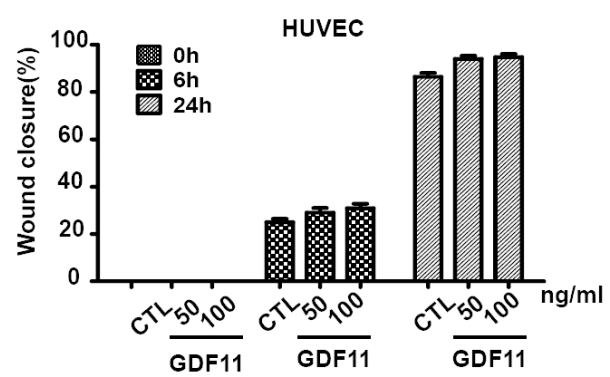

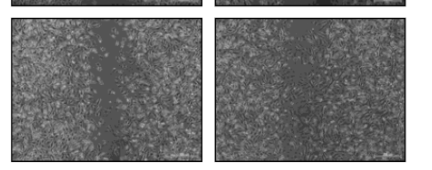

HUVEC
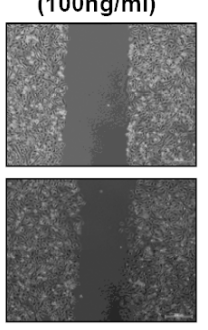

C

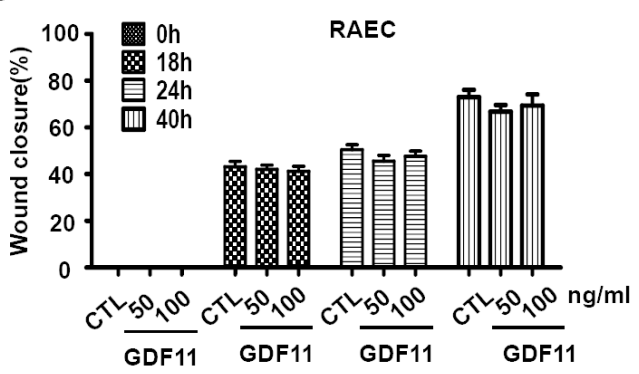

GDF11 GDF11 GDF11

Figure 8: GDF11 shows no significant effect on cell migration in HUVECs and RAECs. A. The representative photographs of wound closure in HUVECs were shown in A. and the summarized data was shown in B.. $n=43$. C. GDF11 showed no significant effect on cell migration in RAECs (rat aorta endothelial cells). $n=15$.
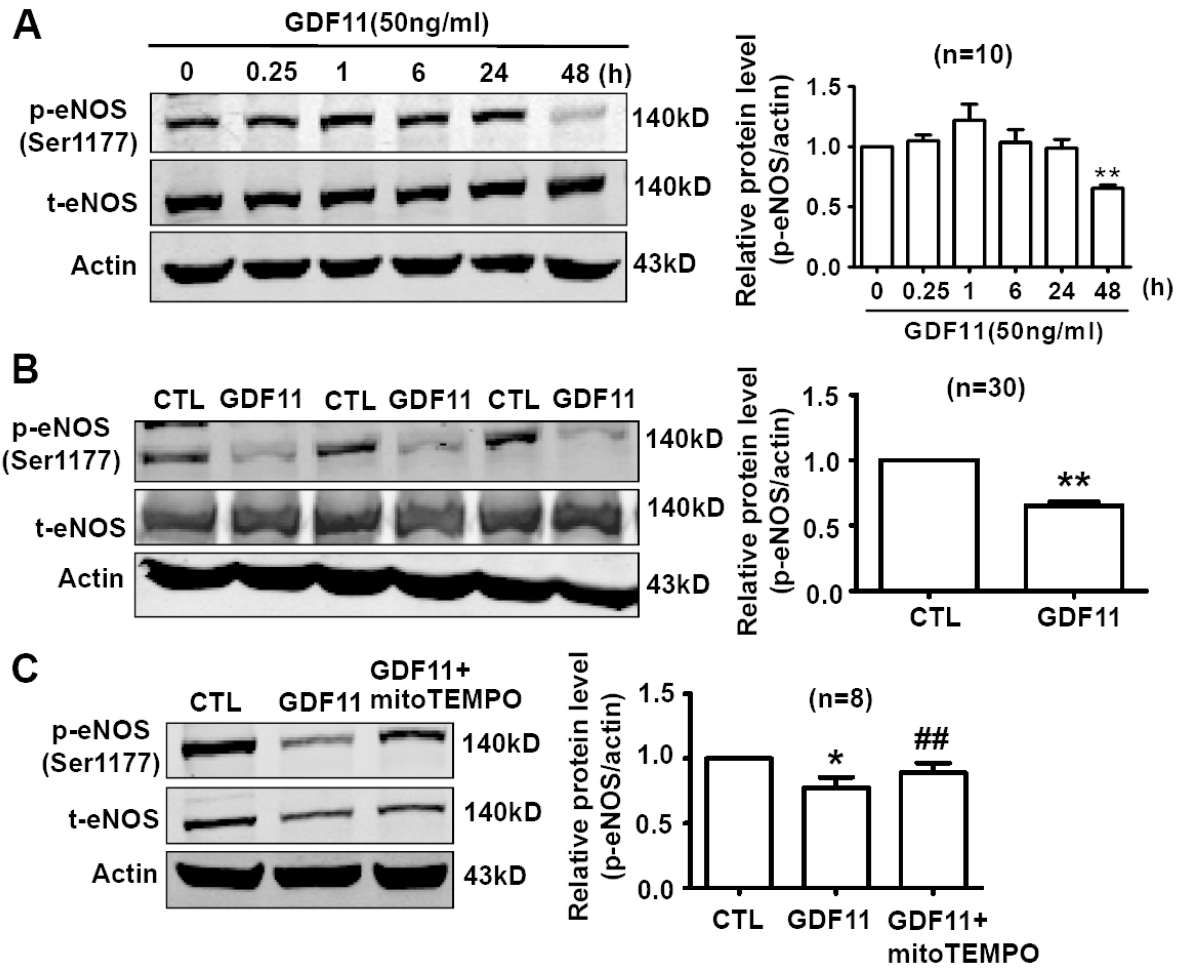

Figure 9: GDF11 decreases the phosphorylation level of eNOS (Ser1177) in HUVECs. A. The time-course of eNOS expressions showed that GDF11 significantly reduced p-eNOS(Ser1177) expression in protein level after $48 \mathrm{~h}$ treatment. $* * P<0.01 v s .0 \mathrm{~h}$. $n=10$. B. Compared with parallel control, GDF11 reduced p-eNOS(Ser1177) expression in protein level after 48h treatment. $* * P<0.01$ vs. Control. $n=30$. C. GDF11-induced decrease of p-eNOS(Ser1177) protein level was restored by antioxidant mitoTEMPO (25nM). The cells were pre-treated by mitoTEMPO for $1 \mathrm{~h}$ and then GDF11 $(50 \mathrm{ng} / \mathrm{ml})$ was added. ${ }^{*} P<0.05$ vs. control.\#\# $P<0.01 v s$. GDF11-treated group. $n=8$. 


\section{Effects of GDF11 on cell viability under serum- deprivation culture condition}

The serum-deprivation cell culture condition is mostly used in the studies on cytokines [23]. It should be noticed that serum-deprivation significantly decreased the cell viability, and serum-deprivation induced apoptosis is observed in a variety of cells including endothelial cells [24-27]. Furthermore, the serum-deprivation condition can not mimic any conditions in vivo. Therefore, we did not think that the serum-deprivation was a reasonably experimental condition for GDF11 study. Nevertheless, GDF11 was reported to increase proliferation of brain capillary endothelial cells in serum-free basal medium previously [5], we also examined the effects of GDF11 in serum-deprivation culture condition. After GDF11 (from PeproTech and R\&D Systems) treatment, cell viability increased significantly in serum-deprivation condition after 24h treatment (Figure 10A and 10B). In serumdeprivation condition, GDF11 still activated $\operatorname{smad} 3$ which was inhibited by smad3 inhibitor SIS3 $(5 \mu \mathrm{M})$ (Figure $10 \mathrm{C}$ ), and SIS3 inhibited GDF11-induced increase of cell viability (Figure 10D). We also found that TGF- $\beta 1$ and fetal bovine serum supplement had the similar effects of increasing cell viability as GDF11 in serum-deprivation culture condition (Figure 10E and 10F), indicating that the effect of GDF11 was not unique.

\section{DISCUSSION}

Identifying the molecular mechanism of rejuvenation is important for developing therapies to treat age-related diseases. Recently, GDF11/BMP11 was suggested as an anti-aging agent. GDF11 not only rejuvenated heart and skeletal muscle in aged mice [4], but also increased proliferation of brain capillary endothelial cells and improved the vascular and neurogenic rejuvenation of the aging mouse brain [5]. However, recent studies questioned this opinion and reported a potent inhibitory effect of GDF11 on skeletal muscle regeneration [8]. Then, a series of studies showed that GDF11 had no positive role in rescuing aging-related pathological hypertrophy and the level of circulating GDF11 in aging animals was not decreased [7-9]. Because GDF11 was reported to increase proliferation of brain capillary endothelial cells and improve blood vessel architecture, we hypothesized that GDF11 would increase the cell viability, proliferation and migration of human umbilical vein endothelial cells. Therefore, we investigated the effects of GDF11 on smad and non-smad signals, cell viability, proliferation and migration in HUVECs. In the present study, we found that GDF 11 activated both smad $1 / 5 / 8$ and smad2/3 signals, showed slight effect on cell viability, but had no significant
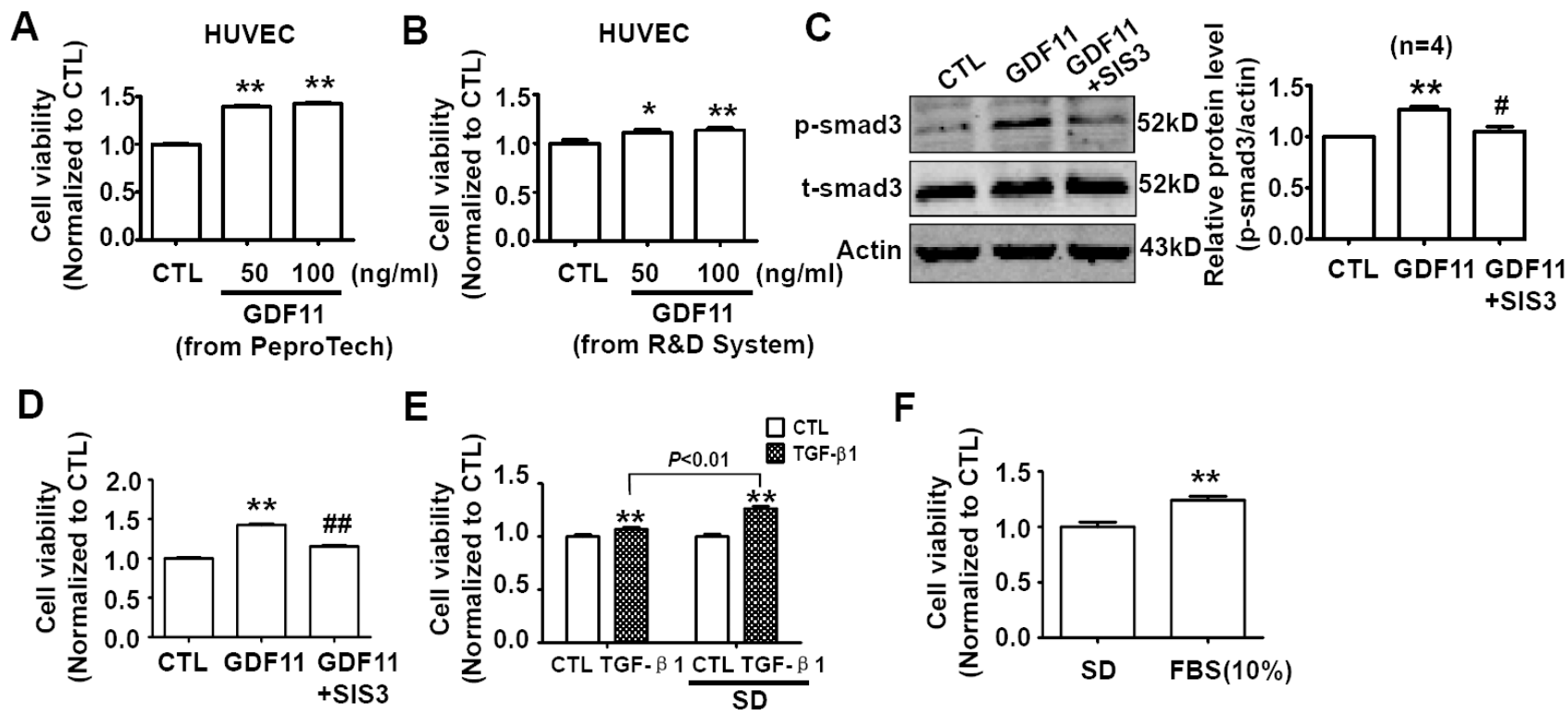

Figure 10: Effects of GDF11 on cell viability of HUVECs in serum-deprivation culture condition. A. GDF11 (50ng/ml and $100 \mathrm{ng} / \mathrm{ml}$ ) purchased from PeproTech increased cell viability of HUVECs after $24 \mathrm{~h}$ treatment in serum-deprivation culture condition. $* * P<0.01 \mathrm{vs}$. control. $n=36$. B. GDF11 $(50 \mathrm{ng} / \mathrm{ml}$ and $100 \mathrm{ng} / \mathrm{ml})$ purchased from R\&D Systems increased cell viability of HUVECs after $24 \mathrm{~h}$ treatment in serum-deprivation culture condition. ${ }^{*} P<0.05$, ${ }^{*} P<0.01 v$ s. control. $n=12$. C. SIS3 (5 $\left.\mu \mathrm{M}\right)$ inhibited GDF11-induced smad3 activation in HUVECs. The cells were pre-treated by SIS3 $(5 \mu \mathrm{M})$ for $1 \mathrm{~h}$ and then GDF11 $(50 \mathrm{ng} / \mathrm{ml})$ was added. $* * P<0.01 v s$. control. \# $P<0.05 v s$. GDF11 treatment group. D. SIS3 $(5 \mu \mathrm{M})$ inhibited GDF11-induced increase of cell viability of HUVECs in serumdeprivation culture condition. ${ }^{*} P<0.01 v s$. control. \#\# $P<0.01 v s$. GDF11 treatment group. $n=36$. E. TGF- $\beta 1$ (100ng/ml) increased cell viability in normal and serum-deprivation culture condition after $24 \mathrm{~h}$ treatment. The effect of increasing cell viability was more significant in serum-deprivation (SD) than in normal culture condition after $24 \mathrm{~h}$ treatment. $* * P<0.01 v s$. control. $n=24$. F. Fetal bovine serum $(10 \%)$ supplement increased cell viability comparing with serum-deprivation condition. $* * P<0.01 v$ s. control. $\mathrm{n}=12$. FBS, fetal bovine serum. 
effect on the proliferation and migration in HUVECs under complete culture medium containing serum.

In our study, we adopted complete medium containing serum to culture the cells. Katsimpardi L et al. found that GDF11 increased proliferation of primary brain capillary endothelial cells under serum deprivation condition, which was consistent with our results that GDF11 increased cell viability under serum-free culture condition (Figure 10A and 10B) [5]. However, whatever in physiological or pathological conditions in vivo, it is impossible for vascular endothelial cells to be alive without serum; even in aging state in vivo, endothelial cells are still in the condition containing serum. Therefore, we hold the opinion that it was not convincing that cells were cultured in serum-free medium to observe the effects of GDF11. Serum-free culture condition is usually used to eliminate interference from the cytokines in serum. For example, Katsimpardi L et al. studied the function of GDF11 on brain capillary endothelial cells in serumfree basal medium for 6 days [5]. However, we found that the morphology of endothelial cell significantly altered under serum-free medium after $24 \mathrm{~h}$ culturing, and the cell viability decreased when the cells were cultured in serum-free medium. Many works have confirmed that serum deprivation induced apoptosis in a variety of cells including endothelial cells [24-27]. Therefore, the medium containing serum was used to culture cells in our study. Under our experimental conditions, we found that GDF11 significantly activated smad $2 / 3$ and smad $1 / 5 / 8$ signals, indicating that the effects of GDF11 could be detected in the presence of serum.

In the present study, although both $\operatorname{smad} 2 / 3$ and smad $1 / 5 / 8$ signals were strongly activated by GDF 11 in HUVECs, the cell proliferation and migration were not significantly increased or decreased. It was possibly due to the mutual effect of $\operatorname{smad} 2 / 3$ and smad1/5/8 signals. Most studies about GDF 11 focused on the smad $2 / 3$ signals related to diverse physical and pathological processes $[4$, $28,29]$. As a member of BMP/TGF- $\beta$ superfamily, we hypothesized that GDF11 should have the action with properties of both BMP and TGF- $\beta$ family, and, indeed, we found that GDF11 activated not only $\operatorname{smad} 2 / 3$, but also smad1/5/8 in HUVECs. Both smad1/5/8 and smad2/3 signals are essential for endothelial function. Some reports suggested that $\mathrm{smad} 2 / 3$ signal was a positive role in endothelial cell function. For example, TGF- $\beta$ promoted cell proliferation, migration and angiogenesis through smad3/NOX4/ $\mathrm{H}_{2} \mathrm{O}_{2}$ signal [15]. However, it was also reported that the activation of $\operatorname{smad} 2 / 3$ signal could inhibit endothelial cell proliferation and cell migration [30]. Similarly, smad1/5/8 showed a controversial effect in endothelial cells. BMP9-induced the activation of ALK1 inhibited endothelial proliferation, migration and angiogenesis [31] and TGF- $\beta$-induced activation of ALK1 promoted the endothelial cell proliferation and migration [32]. Meanwhile, the $\operatorname{smad} 2 / 3$ and $\operatorname{smad} 1 / 5 / 8$ signals interacted on each other. TGF- $\beta$-induced ALK1 signal inhibited TGF- $\beta$-induced ALK-5 signal in the regulation of endothelial cell behavior [30]. In the course of differentiation of endothelial cells from bone marrow mesenchymal stem cells, smad3 promoted differentiation at an early phase, suppressed differentiation later and the activation of smad1/5/8 at a low level can promote differentiation [33]. Collectively, there existed a balance between $\operatorname{smad} 2 / 3$ and smad1/5/8 signals. Besides the canonical smad signal, GDF11 also activated JNK and AMPK signals. MitoTEMPO, which is a mitochondrialtargeted ROS inhibitor, restored GDF11-induced JNK and AMPK activation, indicating that GDF11-induced JNK and AMPK activation was secondary to ROS.

GDF11 induced an increase of NOX4 expression in HUVECs. NOX4 was reported to generate $\mathrm{O}^{2-}$ and $\mathrm{H}_{2} \mathrm{O}_{2}$, which could increase cell viability and migration of endothelial cell at a lower dose and induce endothelial apoptosis at a higher dose [20]. Thus, with the increase of NOX4 expression in HUVECs, ROS generation would gradually increase in the cells, which was similar to the treatment of tert-Butyl hydroperoxide with different concentrations (Figure 6A). However, it was notable that, although GDF11 slightly decreased cell viability, it did not induce cell death as demonstrated by live and dead cell staining assay (Figure 6C). Besides, whatever the increase of cell viability for short time treatment or decrease of cell viability for long time treatment, the difference was meaningless from the professional point of view.

In conclusion, we found GDF11 activated both smad1/5/8 and smad2/3 signals in HUVECs but showed no significant effect on cell migration and proliferation. Comparing with TGF- $\beta 1$, the effect of GDF11 was also not unique. The present work suggests that the notion of GDF11 as a rejuvenation-related factor for endothelial cells needs to be cautious.

\section{MATERIALS AND METHODS}

\section{Agents}

Human umbilical vein endothelial cell (HUVEC) was purchased from Bioleaf (Shanghai, China). Dulbecco's modified Eagle's medium (DMEM) was purchased from Hyclone (Logan, Utah, USA). Fetal bovine serum (FBS) was purchased from Biological Industries (Beit Haemek, Israel). Recombinant human GDF-11 and recombinant human/mouse/rat GDF-11 were obtained from PeproTech and R\&D Systems, respectively. AntiNOX4, anti-smad1/5/8 and smad3 inhibitor SIS3 were purchased from Santa Cruz (Eugene, OR, USA). Anti-peNOS (Ser1177), anti-eNOS, anti-p-smad1(Ser463/465)/ smad5(Ser463/465)/smad8(Ser426/428), antip-smad3(Ser423/425), anti-smad3, anti-p- 
smad2(Ser465/467), anti-smad2, anti-smad2/3, anti-p-Akt(Ser473), anti-p-Akt(Thr308), anti-Akt, antip-p38(Thr180/Tyr182), anti-p38, anti-p-JNK(Thr183/ Tyr185), anti-JNK, anti-p-Erk1/2(Thr202/Tyr204), antiErk1/2, anti-p-AMPKa(Thr172), anti-AMPKa were obtained from Cell signal technology(Beverly, MA, USA). Anti-actin was obtained from ZSGB-BIO(Beijing, China). IRDye $800 \mathrm{CW}$ goat anti-mouse and IRDye $800 \mathrm{CW}$ goat anti-rabbit were purchased from Licor (Lincoln, Nebraska, USA). MitoTEMPO, Type IA collagenase and tert-Butyl hydroperoxide solution were purchased from SigmaAldrich (St. Louis, MO, USA). CFSE cell proliferation kit was obtained from Beyotime (Shanghai, China). LIVE/ DEAD $\circ$ RRViability/Cytotoxicity Assay Kit was obtained from Invitrogen (Eugene, OR, USA). MTT and dimethyl sulfoxide were obtained from Amresco (Solon, OH, USA). DMSO (dimethyl sulfoxide) was as solvent for stocking solution and its final concentration was limited within 4\%o, which showed no effect on cell viability. Unless otherwise stated, GDF11 purchased from PeproTech was used.

\section{HUVEC cell culture}

HUVEC cells were cultured in Dulbecco's modified Eagle's medium supplemented with $10 \%$ fetal bovine serum, 100 units $/ \mathrm{ml}$ penicillin and $100 \mu \mathrm{g} / \mathrm{ml}$ streptomycin at $37^{\circ} \mathrm{C}, 5 \% \mathrm{CO}_{2}$. The time of treatment and concentration of agents were shown in Figures and/or corresponding Figure legends.

\section{Primary rat aortic endothelial cell}

Adult Sprague Dawley rats were anesthetized with pentobarbital sodium by intraperitoneal injection. Heparin (100units/mL) in phosphate buffer saline (PBS) was infused into heart from the view of the left ventricle and the abdominal aorta was cut off in order to remove the blood of vessel. Then the aorta was dissected in PBS containing $1 \%$ penicillin-streptomycin and aorta was incubated in collagenase type I solution for $10 \mathrm{~min}$ at $37^{\circ} \mathrm{C}$. Endothelial cells were collected by centrifugation, resuspended in 20\% FBS-DMEM, and then endothelial cells were cultured. The detailed procedure was described [34]. All procedures involving animals and their care were approved by the Institutional Animals Care and Use Committee of Harbin Medical University, PR China.

\section{Western blot analysis}

Western blot analysis was performed as described in our previous work $[35,36]$. Cells were lysed with RIPA buffer containing $1 \%$ protease inhibitor, $10 \%$ phosphatase inhibitor and centrifuged at $13500 \mathrm{r}$ for $15 \mathrm{~min}$ at $4^{\circ} \mathrm{C}$. Then the supernatants were collected and the protein concentrations were determined by BCA assay kit (Beyotime, China). The protein was applied to $8 \%$ to $12 \%$ SDS-PAGE gels, transferred to nitrocellulose membranes. After incubation with the proper primary and secondary antibodies, Western blot bands were quantified by using Odyssey infrared imaging system (LI-COR) and Odyssey v3.0 software.

\section{MTT assay}

Cell viability was assessed by MTT assay (tetrazolium bromide reduction) to measure mitochondrial succinate dehydrogenase activity in living cells. The assay is dependent on the ability of viable cells to metabolize a water-soluble tetrazolium salt into a water-insoluble formazan product. Cells were trypsinized and seeded in the 96-well plate. After adherence, complete medium was replaced with basal medium for 12 hours. The time of treatment and concentration of agents were shown in Figures and/or corresponding Figure legends.

\section{Cell wound healing assay}

The wound-healing assay was used to determine cell migration ability. HUVECs were collected and subcultured with DMEM containing 10\% FBS in six-well plate. A scratch was made by using a pipette tip on a uniform layer of cells. The scratch was washed with PBS twice to remove detached cells. The images were monitored at $0 \mathrm{~h}, 6 \mathrm{~h}$ and $24 \mathrm{~h}$ for HUVECs and $0 \mathrm{~h}, 18 \mathrm{~h}$, $24 \mathrm{~h}$ and $40 \mathrm{~h}$ for RAECs after scratching at the same area by taking photos with microscope at $4 \times 10$ magnification to measure the width of wound. The wound widths of different areas at different time points were measured with Image J software.

\section{Cell proliferation assay}

Cell proliferation was measured by carboxyfluorescein diacetate succinimidyl ester (CFSE) staining. Endothelial cells were collected and suspended with DMEM containing 10\% FBS, and then immediately labeled with CFDA SE $(5 \mu \mathrm{M})$ in the same volume under the condition of $37^{\circ} \mathrm{C}, 5 \% \mathrm{CO}_{2}$ for $10 \mathrm{~min}$. The staining was terminated by $40 \%$ volume precooling FBS for 10 min. Suspension cells were centrifuged at $1000 \mathrm{rpm}$ for 5 min. The supernatant was discarded and washed by PBS buffer twice. Re-suspended endothelial cells were cultured in DMEM with $10 \%$ FBS under $37^{\circ} \mathrm{C}, 5 \% \mathrm{CO}_{2}$ for $24 \mathrm{~h}$. The cells were collected by centrifuging at $1000 \mathrm{rpm}$ for 5 min, washed by PBS buffer and re-suspended by PBS buffer. The samples were filtered by 200 mesh strainer and analyzed by flow cytometry (excitation: $492 \mathrm{~nm}$; emission: $517 \mathrm{~nm}$ ). The cell proliferation is negatively correlated to 
the intensity of fluorescence.

\section{Live and dead cell staining}

The cells were seeded in the six-well plate at a density of $3.75 \times 10^{4} / \mathrm{mL}$. After adherence, complete medium was replaced with basal medium for 12 hours. The time of treatment and concentration of agents were shown in Figures and/or corresponding Figure legends. Then the cells were washed with PBS for three times and stained according to the manufacturer's instructions. The labeled cells were photographed under a fluorescence microscope. The live cells were stained with calcein AM in green, and the dead cells were stained with ethidium homodimer-1 in red.

\section{Data analysis}

Data are presented as mean \pm SEM. Significance was determined by using Student $\mathrm{t}$ test or one-way ANOVA, followed by Holm-Sidak post test. $P<0.05$ was considered significant.

\section{ACKNOWLEDGMENTS}

This work was supported by the National Basic Research Program of China (Grant No. 2012CB517803) and the National Natural Science Foundation of China (Grant No. 81421063, 81373406).

\section{Authors' contributions}

Yong-Hui Zhang, Feng Cheng, Xue-Ting Du, Jin-Lai Gao, Xiao-Lin Xiao, Na Li and Shan-Liang Li performed the cell culture, western blot, MTT assay, cell wound healing assay, cell proliferation assay, and live and dead cell staining. De-Li Dong designed the project and wrote the paper.

\section{CONFLICTS OF INTEREST}

The authors declare no conflict of interest.

\section{REFERENCES}

1. Nakashima M, Toyono T, Akamine A, Joyner A. Expression of growth/differentiation factor 11, a new member of the BMP/TGFbeta superfamily during mouse embryogenesis. Mech Develop. 1999; 80:185-189.

2. Yokoe $\mathrm{T}$, Ohmachi $\mathrm{T}$, Inoue $\mathrm{H}$, Mimori $\mathrm{K}$, Tanaka F, Kusunoki M and Mori M. Clinical significance of growth differentiation factor 11 in colorectal cancer. Int J Oncol. 2007; 31:1097-1101.
3. Shimajiri Y, Kosaka Y, Scheel DW, Lynn FC, Kishimoto N, Wang J, Zhao S and German MS. A mouse model for monitoring islet cell genesis and developing therapies for diabetes. Dis Mod Mech. 2011; 4:268-276.

4. Loffredo FS, Steinhauser ML, Jay SM, Gannon J, Pancoast JR, Yalamanchi P, Sinha M, Dall'Osso C, Khong D, Shadrach JL, Miller CM, Singer BS, Stewart A, Psychogios N, Gerszten RE, Hartigan AJ, et al. Growth differentiation factor 11 is a circulating factor that reverses age-related cardiac hypertrophy. Cell. 2013; 153:828-839.

5. Katsimpardi L, Litterman NK, Schein PA, Miller CM, Loffredo FS, Wojtkiewicz GR, Chen JW, Lee RT, Wagers $\mathrm{AJ}$ and Rubin LL. Vascular and neurogenic rejuvenation of the aging mouse brain by young systemic factors. Science. 2014; 344:630-634.

6. Finkenzeller G, Stark GB, Strassburg S. Growth differentiation factor 11 supports migration and sprouting of endothelial progenitor cells. J Surg Res. 2015; 198:50-56.

7. Rodgers BD and Eldridge JA. Reduced Circulating GDF11 Is Unlikely Responsible for Age-dependent Changes in Mouse Heart, Muscle, and Brain. Endocrinology. 2015; 156:3885-3888.

8. Egerman MA, Cadena SM, Gilbert JA, Meyer A, Nelson HN, Swalley SE, Mallozzi C, Jacobi C, Jennings LL, Clay I, Laurent G, Ma S, Brachat S, Lach-Trifilieff E, Shavlakadze T, Trendelenburg AU, et al. GDF11 Increases with Age and Inhibits Skeletal Muscle Regeneration. Cell Metab. 2015; 22:164-174.

9. Smith SC, Zhang X, Zhang X, Gross P, Starosta T, Mohsin S, Franti M, Gupta P, Hayes D, Myzithras M, Kahn J, Tanner J, Weldon SM, Khalil A, Guo X, Sabri A, et al. GDF11 Does Not Rescue Aging-Related Pathological Hypertrophy. Circ Res. 2015; 117:926-932.

10. Jian J, Sun L, Cheng X, Hu X, Liang J, Chen Y. Calycosin-7-O- $\beta$-d-glucopyranoside stimulates osteoblast differentiation through regulating the BMP/WNT signaling pathways. Acta Pharm Sin B. 2015; 5:454-460.

11. Dwivedi SK, McMeekin SD, Slaughter K and Bhattacharya R. Role of TGF-beta signaling in uterine carcinosarcoma. Oncotarget. 2015; 6:14646-14655. doi: 10. 18632/ oncotarget. 3711.

12. Sturrock A, Cahill B, Norman K, Huecksteadt TP, Hill K, Sanders K, Karwande SV, Stringham JC, Bull DA, Gleich M, Kennedy TP and Hoidal JR. Transforming growth factor-betal induces Nox4 NAD(P)H oxidase and reactive oxygen species-dependent proliferation in human pulmonary artery smooth muscle cells. Am J Physiol Lung Cell Mol Physiol. 2006; 290:L661-L673.

13. Hecker L, Vittal R, Jones T, Jagirdar R, Luckhardt TR, Horowitz JC, Pennathur S, Martinez FJ and Thannickal VJ. NADPH oxidase-4 mediates myofibroblast activation and fibrogenic responses to lung injury. Nat Med. 2009; 15:1077-1081.

14. Boudreau HE, Casterline BW, Rada B, Korzeniowska A 
and Leto TL. Nox4 involvement in TGF-beta and SMAD3driven induction of the epithelial-to-mesenchymal transition and migration of breast epithelial cells. Free Radic Biol Med. 2012; 53:1489-1499.

15. Peshavariya HM, Chan EC, Liu GS, Jiang F, Dusting GJ. Transforming growth factor- $\beta 1$ requires NADPH oxidase 4 for angiogenesis in vitro and in vivo. J Cell Mol Med. 2014; 18:1172-1183.

16. Touyz RM and Montezano AC. Vascular Nox4: a multifarious NADPH oxidase. Circ Res. 2012; 110:11591161.

17. Drummond GR and Sobey CG. Endothelial NADPH oxidases: which NOX to target in vascular disease? Trends Endocrinol Metab. 2014; 25:452-463.

18. Zhang YE. Non-Smad pathways in TGF-beta signaling. Cell Res. 2009; 19:128-139.

19. Guo WT and Dong DL. Bone morphogenetic protein-4: a novel therapeutic target for pathological cardiac hypertrophy/heart failure. Heart Fail Rev. 2014; 19:781788.

20. Cai H. Hydrogen peroxide regulation of endothelial function: origins, mechanisms, and consequences. Cardiovasc Res. 2005; 68:26-36.

21. Spector A, Ma W, Sun F, Li D and Kleiman NJ. The effect of $\mathrm{H} 2 \mathrm{O} 2$ and tertiary butyl hydroperoxide upon a murine immortal lens epithelial cell line, alphaTN4-1. Exp Eye Res. 2002; 75:573-582.

22. Das A, Gopalakrishnan B, Druhan LJ, Wang TY, De Pascali F, Rockenbauer A, Racoma I, Varadharaj S, Zweier JL, Cardounel AJ and Villamena FA. Reversal of SIN-1induced eNOS dysfunction by the spin trap, DMPO, in bovine aortic endothelial cells via eNOS phosphorylation. Br J Pharmacol. 2014; 171:2321-2334.

23. Chen X, Liao J, Lu Y, Duan X and Sun W. Activation of the $\mathrm{PI} 3 \mathrm{~K} / \mathrm{Akt}$ pathway mediates bone morphogenetic protein 2-induced invasion of pancreatic cancer cells Panc-1. Pathol Oncol Res. 2011; 17:257-261.

24. Chin BY, Petrache I, Choi AM and Choi ME. Transforming growth factor betal rescues serum deprivation-induced apoptosis via the mitogen-activated protein kinase (MAPK) pathway in macrophages. J Biol Chem. 1999; 274: $11362-$ 11368 .

25. Duttaroy A, Qian JF, Smith JS, Wang E. Up-regulated P21CIP1 expression is part of the regulation quantitatively controlling serum deprivation-induced apoptosis. J Cell Biochem. 1997; 64:434-446.

26. Hogg N, Browning J, Howard T, Winterford C, Fitzpatrick D, Gobe G. Apoptosis in vascular endothelial cells caused by serum deprivation, oxidative stress and transforming growth factor-beta. Endothelium. 1999; 7:35-49.

27. Kim YM, Kim JH, Kwon HM, Lee DH, Won MH, Kwon YG and Kim YM. Korean Red Ginseng protects endothelial cells from serum-deprived apoptosis by regulating Bcl2 family protein dynamics and caspase S-nitrosylation. J
Ginseng Res. 2013; 37: 413-424.

28. Gaunt SJ, George M, Paul YL. Direct activation of a mouse Hoxd11 axial expression enhancer by Gdf11/Smad signalling. Dev Biol. 2013; 383:52-60.

29. Poggioli T, Vujic A, Yang P, Macias-Trevino C, Uygur AN, Loffredo FS, Pancoast JR, Cho M, Goldstein J, Tandias RM, Gonzalez E, Walker RG, Thompson TB, Wagers AJ, Fong YW, Lee RT. Circulating Growth Differentiation Factor 11/8 Levels Decline with Age. Circ Res. 2016; 118:29-37.

30. Lebrin F, Deckers M, Bertolino P and Ten Dijke P. TGFbeta receptor function in the endothelium. Cardiovasc Res. 2005; 65:599-608.

31. Scharpfenecker M, van Dinther M, Liu Z, van Bezooijen RL, Zhao Q, Pukac L, Lowik CW and ten Dijke P. BMP-9 signals via ALK1 and inhibits bFGF-induced endothelial cell proliferation and VEGF-stimulated angiogenesis. J Cell Sci. 2007; 120:964-972.

32. Goumans MJ, Valdimarsdottir G, Itoh S, Rosendahl A, Sideras P and ten Dijke P. Balancing the activation state of the endothelium via two distinct TGF-beta type I receptors. EMBO J. 2002; 21:1743-1753.

33. Ai WJ, Li J, Lin SM, Li W, Liu CZ and Lv WM. R-smad signaling-mediated VEGF expression coordinately regulates endothelial cell differentiation of rat mesenchymal stem cells. Stem Cells Dev. 2015; 24:1320-1331.

34. Tian XY, Wong WT, Wang N, Lu Y, Cheang WS, Liu J, Liu L, Liu Y, Lee SS, Chen ZY, Cooke JP, Yao X and Huang Y. PPAR $\delta$ activation protects endothelial function in diabetic mice. Diabetes. 2012; 61:3285-3293.

35. Sheng Y, Sun B, Guo WT, Liu X, Wang YC, Xie X, Xiao $\mathrm{XL}, \mathrm{Li} \mathrm{N}$ and Dong DL. (4- [6-(4-isopropoxyphenyl) pyrazolo [1,5-a]pyrimidin-3-yl] quinoline) is a novel inhibitor of autophagy. Br J Pharmacol. 2014; 171:49704980.

36. Xie X, Zhao Y, Ma CY, Xu XM, Zhang YQ, Wang CG, Jin J, Shen X, Gao JL, Li N, Sun ZJ and Dong DL. Dimethyl fumarate induces necroptosis in colon cancer cells through GSH depletion/ROS increase/MAPKs activation pathway. Br J Pharmacol. 2015; 172:3929-3943. 